\title{
Peningkatan Kompetensi Civitas Universitas Muhammadiyah Jakarta Terkait Produksi Kampanye Public Relations di Masa Pandemi
}

\author{
Syifa Astasia Utari ${ }^{1^{*}}$, Winda Dwiastuti Zebua ${ }^{1}$ \\ Ilmu Komunikasi, Fakultas Ilmu Sosial dan Ilmu Politik, Universitas Muhammadiyah Jakarta, \\ Jl. K.H. Ahmad Dahlan, Cireundeu, Kec. Ciputat Tim., Kota Tangerang Selatan, Banten 15419 \\ Email penulis korespondensi: syifaastasia@gmail.com
}

\begin{abstract}
Various lines of people's lives have also been affected by the existence of Covid-19, various efforts are also being made to reduce the growth rate of Covid-19 in Indonesia, starting from large-scale social restrictions, implementing health protocols, to public education about the importance of a healthy lifestyle. This condition requires the government and other stakeholders to be able to properly and accurately disseminate information related to this issue to the public, one of which is by promoting campaigns. Campaigns that are intensified are considered capable of shaping public perceptions about an issue, but sometimes the validity of messages circulating still needs to be questioned, causing misinformation and the potential to become hoaxes, for example, the campaign around the Covid-19 Vaccine. This program seeks to improve the competence of participants through sharing knowledge about the production and distribution of campaigns in the field so that the UMJ community can contribute to reducing the community through the campaigns they create. This community service method is in the form of talk shows and training on creating campaigns through webinars at Zoom meetings and live streaming on Youtube of FISIP UMJ, with the title Communicatalks: Public Relations Campaign Trends in the Pandemic Period and collaborating with KEMENPPPA Public Relations as a case study. As the results of this activity, the participants were able to create quality and valid campaign messages so that the risk of disinformation which caused unrest in the community could be minimized, examples of campaign results were published through social media.
\end{abstract}

\section{Keywords: Campaign, Covid-19, Hoax, KEMENPPPA, Public Relations}

\begin{abstract}
Abstrak
Berbagai lini kehidupan masyarakat ikut terkena dampak akibat keberadaan Covid-19, beragam upaya juga terus dilakukan guna menekan angka pertumbuhan Covid-19 di Indonesia, mulai dari kebijakan Pembatasan Sosial Berskala Besar, penerapan protokol kesehatan, hingga edukasi publik mengenai pentingnya pola hidup sehat. Kondisi ini menuntut pemerintah dan stakeholder lainnya untuk mampu mendifusikan informasi terkait isu tersebut kepada masyarakat secara tepat dan akurat, salah satunya adalah dengan menggalakkan kampanye. Kampanye yang digencarkan secara intensif dianggap mampu membentuk persepsi publik mengenai suatu isu, namun terkadang validitas pesan yang beredar masih perlu dipertanyakan sehingga menimbulkan disinformasi dan berpotensi menjadi hoax, misalnya saja kampanye seputar Vaksin Covid-19. Program ini berupaya untuk meningkatkan kompetensi peserta melalui kegiatan sharing knowledge tentang produksi dan distribusi kampanye di lapangan, agar civitas UMJ dapat berkontribusi dalam mengeduksi masyarakat melalui kampanye yang mereka buat. Metode pengabdian masyarakat ini berupa talkshow dan pelatihan pembuatan kampanye melalui webinar di Zoom meeting dan live streaming di Youtube FISIP UMJ, dengan judul Communicatalks: Tren Kampanye Humas di Masa Pandemi dan berkolaborasi dengan Humas KEMENPPPA sebagai studi kasus. Hasil kegiatan ini peserta mampu menciptakan pesan-pesan kampanye yang berkualitas dan valid sehingga resiko disinformasi yang menyebabkan keresahan di masyarakat dapat diminimalisasi, contoh-contoh hasil kampanye dipublikasikan melalui media sosial.
\end{abstract}

Kata Kunci: Covid-19, Hoax, Kampanye, KEMENPPPA, Public Relation 


\section{PENDAHULUAN}

Pada masa pandemi, berbagai lini kehidupan masyarakat ikut terkena dampak akibat keberadaan Covid-19, mulai dari kesehatan, keuangan, hingga isu-isu sosial budaya yang erat kaitannya dengan lapisan masyarakat yang tergolong rentan, seperti perempuan, anak, dan lansia. Berbagai upaya untuk menanggulangi dampak dan menekan jumlah penambahan korban Covid-19 terus dilakukan oleh berbagai stakeholder di kalangan masyarakat, mulai dari pemerintah, tenaga kesehatan, termasuk juga di dalamnya para akademisi dari bidang pendidikan. Munculnya kebijakan Pembatasan Sosial Berskala Besar, penerapan protokol kesehatan, hingga edukasi publik mengenai pentingnya pola hidup sehat pun dilakukan secara massive dan intensif melalui berbagai metode. Semua pihak diharapkan bersedia untuk bersinergi dan saling mengelaborasikan bidang keahlian masing-masing demi memberikan kontribusi terbaik bagi negeri yang sedang dilanda kesulitan. Jika dilihat dari sudut pandang bidang komunikasi, seperti yang telah kita ketahui bersama bahwa arus informasi yang terkait Covid-19 semakin hari semakin deras dan tak terbendung lagi jumlahnya. Baik informasi yang menyebar secara intensif melalui media konvensional (tv dan radio), maupun melalui media- media konvergensi seperti internet dan media sosial dalam berbagai format (poster, storytelling, maupun video). Belum lagi beragam sumber informasi non fomal dan tanpa filter juga bermunculan, terutama yang dapat diakses melalui internet menyebabkan kesimpangsiuaran informasi itu sendiri, yang berakhir dengan keresahaan masyarakat akibat munculnya berita-berita yang berpotensi menjadi hoax terlebih yang berkaitan dengan situasi pandemi ini. Kementerian Komunikasi dan Informatika (Kominfo) menemukan ada 1.197 temuan isu hoax di internet seperti media sosial. Kominfo juga menuturkan sudah memblokir 1.759 akun yang menyebar hoax di media social (detik.com, 2020). Lebih rinci Menkominfo Johnny G Plate dalam diskusi survei Indikator Politik Indonesia menyatakan sebanyak 1.197 temuan isu hoax COVID-19 yang tersebar di 4 platform digital sejumlah 2020 sebaran, di Facebook 1.497, di Instagram 20, di Twitter 482, dan di YouTube 21, yang sudah di-takedown, diblokir sebanyak 1.759, di
Facebook 1.300, Instagram 15, Twitter 424, dan YouTube20.

Fenomena ini menyebabkan adanya disinformasi yang mungkin saja dapat berujung pada keresahan dan kepanikan masyarakat. Salah satu bentuk komunikasi yang sedang gencar dilakukan oleh berbagai pihak di masa pandemi saat ini adalah kampanye, hampir semua entitas terlembaga mengeluarkan kampanye sesuai dengan kepentingannya masing-masing (perusahaan profit, BUMN, hingga pemerintah, dan LSM). Regors dan Storey menyatakan bahwa kampanye merupakan serangkaian kegiatan komunikasi yang terorganisir dengan tujuan untuk menciptakan dampak tertentu pada sebagian besar khalayak sasaran secara berkelanjutan dalam periode waktu tertentu" (Ruslan, 2008). Sebagian besar kampanye yang dijalankan oleh berbagai pihak selama pandemi akhir-akhir ini cenderung bernuansa ideological campaign atau yang sering juga disebut sebagai social change campaign. Mulai dari kampanye yang mengangkat isu protokol kesehatan, isu kebijakan publik yang dikeluarkan oleh pemerintah, hingga isu-isu pada sektor lainnya yang juga bersinggungan dengan situasi pandemi.

Mengingat banyaknya kampanye yang digalakkan oleh berbagai pihak di masa pandemik itulah, kami sebagai akademisi tidak jarang menjumpai kampanye yang bernada sarkas dan negatif, yang mungkin saja validitas pesan, kompetensi, dan kredibilitas pelaku kampanye tersebut juga perlu dipertanyakan, karena berpotensi menggiring opini publik terhadap sesuatu yang belum tentu benar faktanya, sehingga munculah banyak hoax akibat adanya disinformasi dan misinterpretasi masyarakat yang terterpa kampaye tersebut. Misalnya saja sebaran kampanye mengenai Vaksin Covid-19, dan Penggunaan Obat Herbal sebagai Penyembuh Covid-19. Salah satu kampanye yang sempat beredar adalah kampanye yang disebut sebagai upaya suatu pihak (Rusia) dalam merusak reputasi vaksin virus corona yang dikembangkan oleh Universitas Oxford Inggris, dengan menyebarkan pernyataan bahwa vaksin tersebut berpotensi mengubah manusia menjadi monyet. Berbagai kampanye dalam bentuk video, foto, dan meme yang dibuat di Rusia telah membanjiri media sosial untuk mendiskreditkan vaksin yang didistribusikan raksasa farmasi Astrazeneca, dengan 
mengklaim vaksin ini menggunakan virus simpanse sebagai vektor.

\section{Waspada! Kampanye Hoax: Vaksin Covid- 19 Bisa Mengubah Manusia Menjadi Monyet}

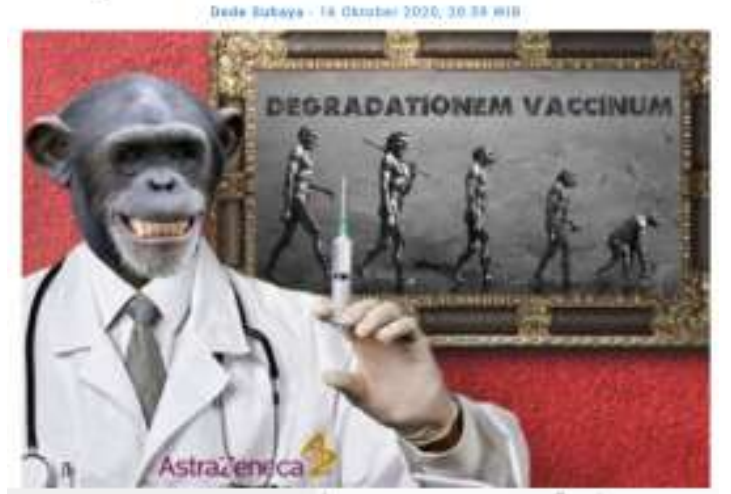

Gambar 1. Contoh kampanye bernada hoax yang beredar di media sosial selama pandemi. (Suhaya, 2020)

Meskipun pada dasarnya kampanye disinformasi tersebut ditujukan untuk menyasar negara-negara Barat di mana Rusia berencana menjual vaksin Covid-19 kontroversialnya yang dinamai Sputnik-V, namun tidak adanya batasan ruang dan waktu di internet membuat pemberitaan tersebut sampai ke tanah air. Hal seperti ini tentu akan menimbulkan efek domino pada kondisi psikologis masyarakat, misalnya saja menimbulkan kepanikan dan chaos akibat disinformasi yang beredar. Oleh karena itu program ini berupaya untuk memberikan pandangan dari perspektif teoretis dan praktis, agar mereka yang tertarik untuk memproduksi dan mendistribusikan sebuah kampanye dapat menciptakan pesan kampanye yang berkualitas dan mampu menyasar kognisi dan afeksi masyarakat secara tepat dengan dukungan kompetensi dan data yang memadai.

Program ini dikemas secara daring melalui Zoom meeting dan live streaming di Youtube FISIP UMJ, dengan judul Communicatalks: Tren Kampanye PR di Masa Pandemi. Di sisi lain, untuk mendapatkan perspektif praktisi kami mengundang pihak pemerintah untuk berkolaborasi dalam program ini untuk dijadikan sebagai studi kasus bagi peserta kegiatan atau mereka yang menonton tayangan Communicatalks. Kementerian Pemberdayaan Perempuan dan Anak dipilih sebagai salah satu contoh kementerian yang secara konsisten melakukan kampanye publik terkait dengan isu-isu yang mencakup lapisan masyarakat yang rentan dan dekat dengan lingkungan kehidupan sehari-hari, dengan situasi pandemi sebagai konteks yang melatarbelakanginya. Seperti kampanye pemberdayaan perempuan, kampanye penggunaan masker pada ibu hamil dan balita atau anak, kampanye protokol kesehatan Keluarga, Jaga Jarak, Tata Cara Bekerja di Rumah Bersama Anak, Keluarga Mampu Bertahan Hidup Hadapi Covid, dan lainnya.

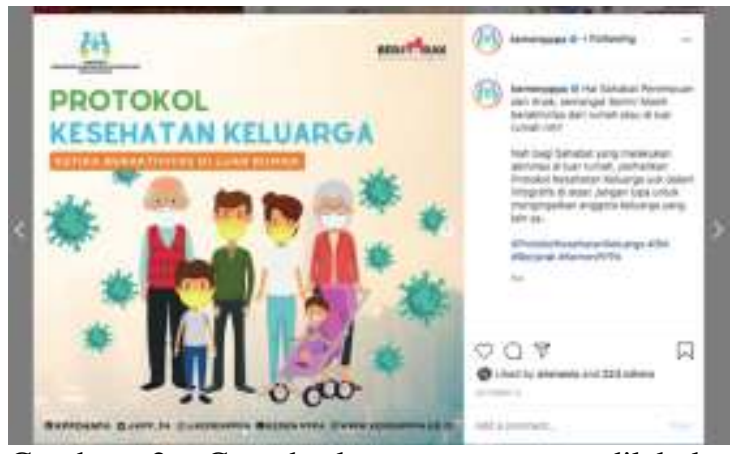

Gambar 2. Contoh kampanye yang dilakukan KEMENPPPA di masa pandemi. (KEMENPPPA, 2020)

Selain kampanye, tentu masih banyak hal lain yang juga dilakukan KEMENPPPA untuk mewujudkan program pemberdayaan perempuan dan anak adalah dengan melakukan pelatihan, edukasi, dan juga menyediakan layanan pengaduan terkait kekerasan perempuan dan anak, semua hal tersebut dilakukan agar masyarakat luas mengerti akan pentingnya kesadaran dan kepedulian terhadap isu kesehatan, perempuan, dan anak yang pada dasarnya merupakan elemen masyarakat yang berperan sebagai fondasi bangsa.

Untuk dapat menciptakan kesadaran sosial, meningkatkan kepedulian, dan menggerakan aksi masyarakat terhadap isu-isu sosial yang berkaitan dengan berbagai permasalahan yang muncul di masa pandemi, tentu saja tidak dapat hanya mengandalkan program-program kampanye yang dijalankan oleh pemerintah saja, tetapi sinergi antar seluruh elemen masyarakat juga dibutuhkan agar permasalahan-permasalahan tersebut dapat diatasi secara optimal. Kesadaran sosial sendiri merupakan presentasi dari persepsi individu tentang informasi yang berhubungan dengan tujuan sosialnya (Sheldon, 1996). Tujuan sosial dalam konteks ini adalah untuk membuat masyarakat lebih peka terhadap kondisi pandemi ini sehingga lebih menjaga dirinya 
sendiri dan orang sekitarnya dari rantai penyebaran virus.

Sebagai bagian dari elemen masyarakat, kalangan akademisi juga dituntut untuk dapat berperan aktif dan berkontribusi dalam mengatasi permasalahan yang menjamur saat ini salah satu diantaranya adalah dengan berpartisipasi dalam kegiatan pengabdian masyarakat yang sekaligus memenuhi Tri Dharma Perguruan Tinggi. Sebagai akademisi dari bidang komunikasi Universitas Muhammadiyah Jakarta, kami mencoba membuat sebuah program untuk memberikan edukasi kepada masyarakat khususnya pelajar yang tertarik terhadap dunia komunikasi yang kemudian kami kerucutkan pada sebuah topik yaitu kampanye. Mengingat banyaknya kampanye yang digalakkan oleh berbagai pihak di masa pandemi, namun sayangnya tidak jarang validitas pesan dan kredibilitas pelaku kampanye yang beredar masih perlu dipertanyakan, bahkan berpotensi menggiring munculnya hoax, akibat adanya disinformasi dan misinterpretasi masyarakat yang terterpa kampaye tersebut. Oleh karena itu program ini berupaya untuk memberikan pandangan dari perspektik teoretis dan praktis, agar mereka yang tertarik untuk memproduksi dan mendistribusikan sebuah kampanye dapat menghasilkan pesan kampanye yang berkualitas dan mampu menyasar kognisi dan afeksi masyarakat secara tepat jika didukung dengan kompetensi yang memadai. Program ini dikemas secara daring melalui Zoom meeting dan live streaming di Youtube FISIP UMJ, dengan judul Communicatalks: Tren Kampanye PR di Masa Pandemi. Pada kesempatan ini, program Communikatalks juga turut menghadirkan praktisi humas dari KEMENPPPA yang dijadikan sebagai studi kasus mengenai produksi dan manajemen kampanye di lingkungan pemerintahan, khususnya yang terkait dengan isu perempuan dan anak, serta situasi pandemi sebagai konteks.

\section{METODE}

\section{Waktu dan Tempat Pelaksanaan}

Program Communicatalks ini dilaksanakan pada hari Sabtu, 12 September 2020, Pukul 09.45 - 12.00 di kediaman masing-masing. Tabel 1 merupakan timeline kegiatan.
Tabel 1. Timeline kegiatan pengabdian kepada masyarakat.

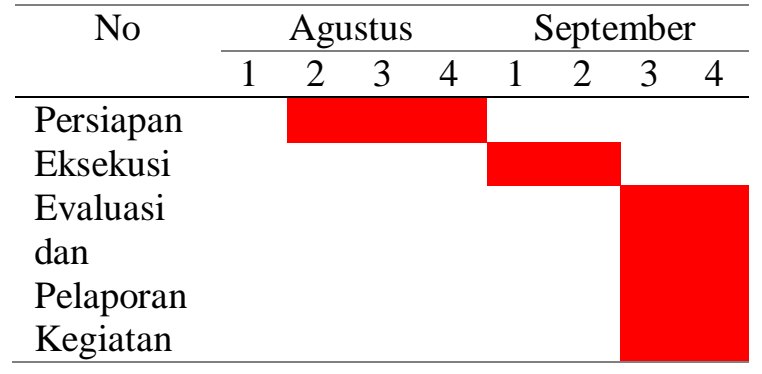

\section{Langkah Pelaksanaan}

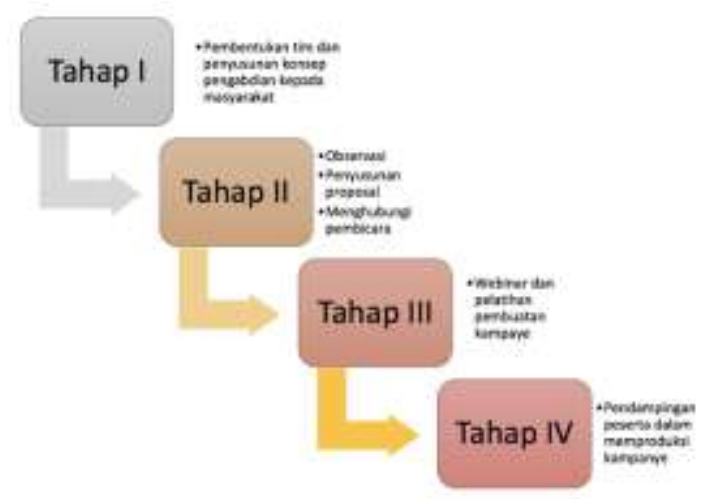

Gambar 3. Alur Langkah pelaksanaan Pengabdian Kepada Masyarakat

Langkah pertama yang dilakukan adalah pembentukan tim yang terdiri dari penulis, Syifa Astasia Utari S.I.Kom., M.Si yang berprofesi sebagai dosen di FISIP Prodi Ilmu Komunikasi, dengan konsentrasi Public Relations juga sering menjadi pembicara dalam pelatihan leadership dan public speaking. Selanjutnya Winda Dwi Astuti Zebua S.Kom.I, M.Si., yang saat ini juga aktif mengajar di FISIP Prodi Ilmu Komunikasi, dengan konsentrasi Public Relations, anggota tim memiliki latar belakang dan keahlian yang sama yaitu dalam bidang komunikasi dan public relations maka, tujuan dari kegiatan pengabdian kepada masyarakat yang akan dilaksanakan ini adalah berbagi ilmu dan edukasi kepada masyarakat luas khususnya mereka yang tertarik dalam bidang komunikasi dan kampanye, juga mahasiswa di bidang serupa.

Pada program ini isu yang diangkat adalah isu-isu yang berkaitan dengan kesehatan, perempuan, dan anak di masa pandemi yang dikemas dalam sebuah kampanye. Hal ini dianggap cukup penting mengingat banyaknya kampanye yang substansi dan kualitasnya tidak sesuai dengan kondisi sosial masyarakat saat 
ini. Selain itu, perlu diketahui bahwa wawasan kampanye sangat luas cakupannya, sehingga pemanfaatannya tidak hanya dapat diaplikasikan dalam ranah politik saja (candidate oriented campaign), tetapi juga dapat diimplementasikan dalam berbagai sektor lainnya, seperti kampanye bisnis (product oriented campaign), juga social change oriented campaign seperti kampanye kesehatan, kampanye lingkungan, juga kampanye tentang isu-isu perempuan, anak, disabilitas, dan lansia yang menjadi studi kasus pada program Communicatalks ini, oleh karena itu kehadiran Alien Chairina Husni, M.Si sebagai perwakilan dari Humas bagian Publikasi dan Media dari KEMENPPPA juga turut melengkapi kegiatan ini. Target sasaran pengabdian masyarakat ini adalah mahasiswa di mana pun berada khususnya di lingkungan UMJ, namun tidak menutup kesempatan untuk masyarakat umum yang tertarik dengan bidang ilmu komunikasi dan pengelolaan kampanye. Program ini dikemas secara daring melalui Zoom meeting dan disiarkan secara live di channel Youtube FISIP UMJ, dengan judul Communicatalks: Tren Kampanye PR di Masa Pandemi dan telah dilaksanakan pada bulan September lalu.

\section{HASIL DAN PEMBAHASAN}

Program Pengabdian Kepada Masyarakat ini berjudul "Communicatalks: Tren Kampaye PR di Masa Pandemi". Program yang dilaksanakan pada tanggal 12 September 2020 ini dilakukan secara streaming online melalui aplikasi zoom meeting dan disiarkan secara langsung melalui saluran Youtube FISIP UMJ, selain itu hasil rekaman diuanggah juga melalui akun yang sama. Program yang berjalan selama kurang lebih 1,5 jam ini membahas tentang segala sesuatu yang berkaitan dengan kampanye humas di masa pandemi, diantaranya meliputi landskap kampanye PR secara teoretis, implementasi kampanye dilengkapi dengan contoh-contohnya, serta studi kasus terkait bentuk-bentuk kampanye yang digunakan untuk mengangkat isu-isu sosial masyarakat ke tengah khalayak, terutama yang terkait dengan isu perempuan dan anak, dengan kondisi pandemi sebagai konteksnya. Isu-isu tersebut diangkat karena program ini juga turut menghadirkan pembicara dari luar UMJ, yaitu praktisi Humas dari KemenPPPA. Penulis sendiri berperan sebagai konseptor, host, moderator, sekaligus pembicara dalam kegiatan ini.

Sesi pemaparan materi dibagi ke dalam tiga sesi, sesi pertama terkait landskap kampanye dilihat dari perspektif teoretis oleh Syifa Astasia Utari, M.Si (penulis), sesi kedua dilanjutkan dengan pemaparan tentang implementasi teori kampanye dalam kegiatan kampanye disertai contoh-contohnya oleh Winda Dwiastuti Zebua, M.Si, dan sesi terakhir pemaparan dari Alien Chairina Husni, M.Si terkait implementasi kampanye di lingkungan pemerintah khususnya di KEMENPPPPA.

Pada sesi pertama, materi merupakan prolog atau materi pembuka yang menguraikan tentang definisi, jenis, efek, dan elemen-elemen vital yang ada dalam suatu kampanye. Selain itu dipaparkan juga tentang bagaimana proses pembuatan kampanye humas, mulai dari perencanaan, pengembangan, eksekusi, hingga evaluasi. Gambaran tentang proses pembuatan proposal kampanye juga turut dipaparkan pada sesi pertama ini. Syifa menyatakan bahwa untuk membuat sebuah kampanye terdapat tiga hal utama yang harus ditentukan terlebih dahulu, yaitu Goals (Tujuan), Message (Pesan), dan Target audience (Khalayak Sasaran). Hal tersebut perlu mendapat perhatian penuh agar kampanye yang dilakukan dapat memberikan efek bagi penerimanya sesuai dengan tataran level efek yang ingin dicapai, baik level awareness (Kesadaran), attitude (sikap), maupun action (tindakan). Hal lain yang tidak kalah penting untuk diperhatikan dalam membuat kampanye adalah kredibilitas dari komunikator, juga kepekaan terhadap kondisi sosial masyarakat yang menjadi khalayak sasaran. Pada masa pandemi seperti ini sebaiknya kampanye dijalankan secara fleksibel, adaptif, dan humanis sesuai dengan kondisi masyarakat Indonesia yang sedang terdampak Covid-19.

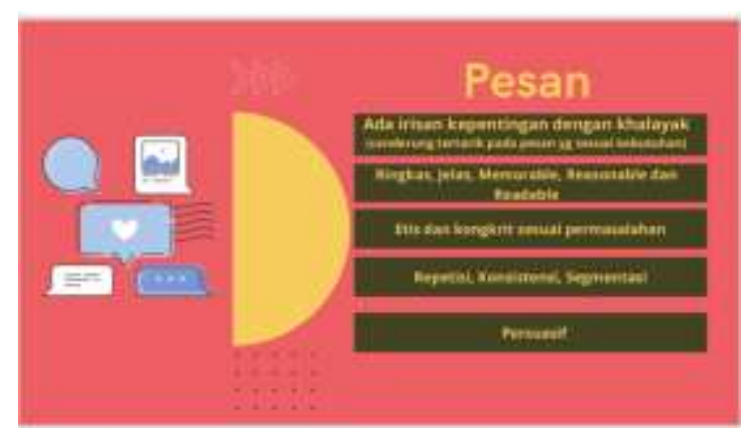




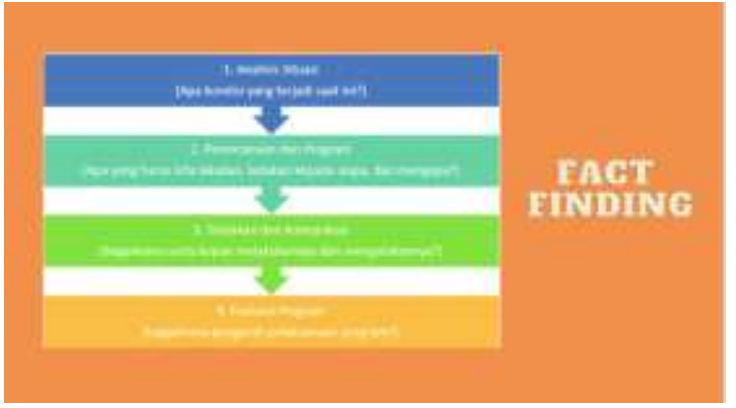

Gambar 4. Contoh materi yang disampaikan Syifa Astasia sebagai akademisi UMJ

Pada sesi kedua, materi yang disampaikan pada dasarnya adalah materi lanjutan dari sesi pertama. Namun, lebih menekankan pada implementasi teori dalam ranah kampanye praktis dengan menunjukkan berbagai jenis dan bentuk penerapan kampanye, strategi, hingga tren kampanye humas yang sering dilakukan oleh instansi-instansi tertentu selama masa pandemi beberapa bulan terakhir. Pada sesi ini juga dibahas tentang pentingnya komunikasi persuasif dalam sebuah kampanye, baik dalam kampanye produk, kandidat, maupun ideologi. Sebagian besar contoh yang disampaikan terkait dengan kampanye seputar ajakan untuk mematuhi protokol kesehatan, seperti memakai masker, menjaga jarak, dan juga himbauan untuk tetap berdiam diri di rumah jika tidak ada kepentingan mendesak. Selain itu disinggung pula tentang bagaimana suatu brand atau perusahaan menghadapi dan menangani situasi pandemi dan mengelola kampanye mereka, di mana kondisi pandemi ini secara signifikan memengaruhi operasional bisnis mereka.

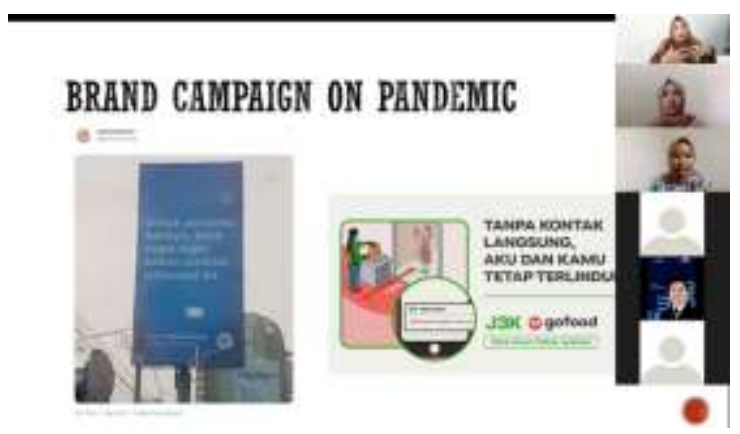

Gambar 5. Contoh materi yang disampaikan Winda Dwiastuti sebagai akademisi UMJ

Pada sesi terakhir, Alien Chairina dari KemenPPPA memaparkan materi dengan judul topik Government PR: From Powerless to Powerfull, yang menuturkan tentang bagaimana situasi pandemi ini justru menjadi momentum kebangkitan bagi humas pemerintah. Pada masa seperti ini, pemerintah sebagai pihak pemegang otoritas secara otomatis menjadi sumber rujukan utama bagi masyarakat untuk mendapatkan informasi yang valid terkait perkembangan kasus Covid-19 di Indonesia, Kebijakan publik yang diambil, serta regulasi yang diterapkan dalam berbagai sektor sebagai tindakan reaktif terhadap dampak yang ditimbulkan oleh Covid-19.

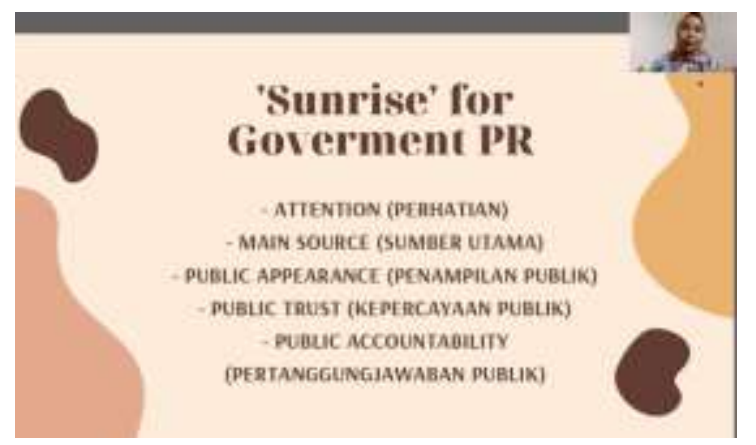

Gambar 6. Contoh materi yang disampaikan Alien Chairina sebagai praktisi Humas Kemenpppa

Alien menjelaskan bahwa pada selama pandemic berlangsung, hampir seluruh kegiatan humas pemerintah khususnya KemenPPPA sebisa mungkin meminimalisasi kegiatan tatap muka dan beralih ke media digital, begitu juga dengan kegiatan humas lainnya termasuk kampanye. KemenPPPA melakukan optimalisasi pada digital asset yang mereka miliki di beberapa platform media sosial, seperti Instagram, website, Youtube, Facebook, dan Twitter. Menurutnya, empat kunci utama agar sebuah kampanye dapat diterima dengan baik oleh khalayak sasaran, yaitu kampanye harus dibuat secara menarik dengan mengedepankan unsur kreativitas, adaptif artinya pesan kampanye yang disampaikan harus disesuaikan dengan kondisi psikososial masyarakat terkini, kolaboratif artinya kampanye dibuat melalui kerjasama dengan berbagai pihak yang memiliki kredibilitas tinggi dalam proses pengumpulan data dan analisis situasi, sehingga kampanye yang dibuat akan menjadi relevan dan sesuai dengan kebutuhan Lembaga dan khalayak penerimanya. Yang terakhir adalah dalam membuat kampanye, seorang praktisi humas harus berani bertindak dan memulai segala hal dengan kemantapan hati dan perencanaan yang matang, termasuk dalam membuat kampanye.

Setelah pembicara memaparkan materinya dilanjutkan dengan pendampingan peserta untuk memproduksi dummy kampanye, mulai 
dari proses fact finding, perencanaan, pembuatan, dan penyebaran kampanye di berbagai media. Pendampingan ini berlangsung secara terbuka selama peserta menghubungi para pembicara yang kontaknya dibagikan saat kegiatan dilangsungkan. Artinya, melalui program pengabdian masyarakat ini maka kompetensi dan pengetahuan para peserta akan literasi produksi kampanye mulai meningkat.
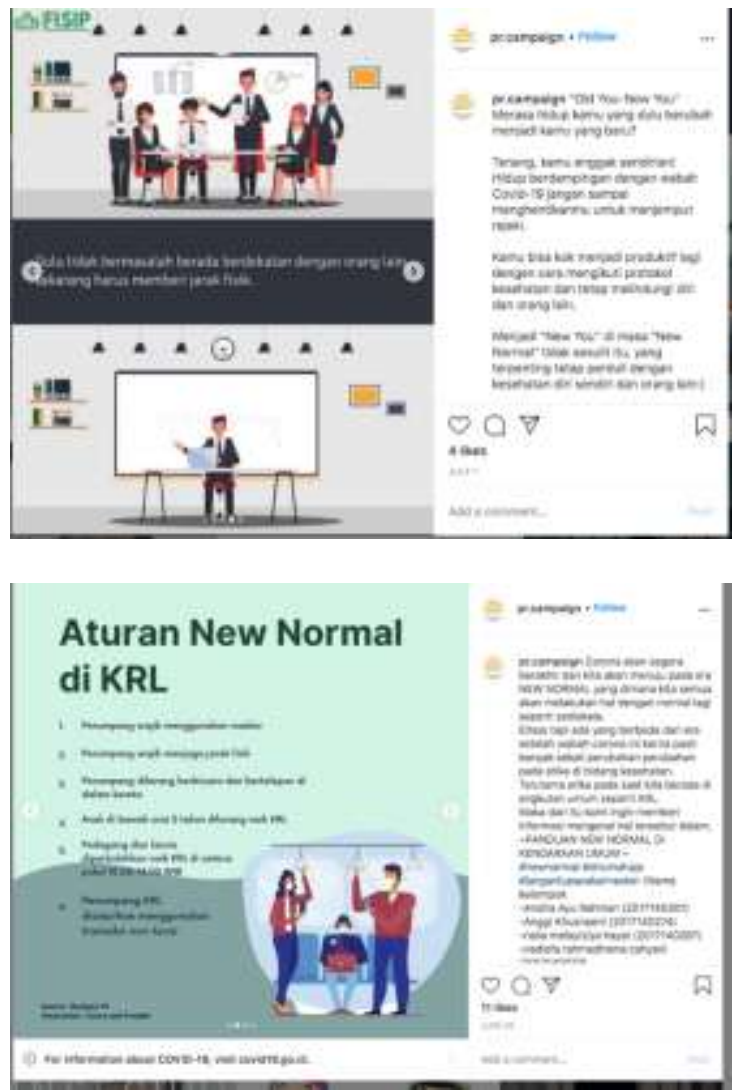

Gambar 6. Contoh Dummy kampanye yang dibuat oleh mahasiswa UMJ

\section{SIMPULAN DAN SARAN}

Program Communicatalks merupakan Program Pengabdian Kepada Masyarakat yang dilakukan dalam rangka memenuhi Tri Dharma Perguruan Tinggi. Program ini dapat dijadikan sebagai salah satu referensi alternatif pengabdian masyarakat yang adaptif di tengah kondisi pandemi Covid-19 seperti sekarang ini. Adapun kegiatan Communicatalks ini pada dasarnya memang bertujuan untuk knowledge sharing kepada para peserta dan masyarakat luas mengenai betapa krusialnya pengelolaan pesan-pesan komunikasi terutama yang terkait dengan pengelolaan kampanye di saat genting seperti ini. Program ini dilakukan agar dapat meningkatkan kompetensi peserta di bidang komunikasi, khususnya yang terkait dengan kemampuan analisis perencanaan, produksi, dan distribusi kampanye. Sehingga nantinya peserta dapat berkontribusi secara aktif dalam menyebarkan informasi yang akurat, membentuk dan mengarahkan perilaku masyarakat yang disesuaikan dengan konteks pandemi ini. Hasil rekaman dapat disaksikan di laman Youtube FISIP UMJ. Sekali lagi, bagi para pelaku kampanye sudah seharusnya memperhatikan aspek kompetensi, media, dan substansi dari pesan yang disampaikan kepada masyarakat, agar tidak menimbulkan disinformasi dan hoax yang mengarah pada kekacauan di tengah masyarakat yang sedang dilanda pandemi.

\section{UCAPAN TERIMA KASIH}

Tim pengabdian masyarakat mengucapkan terima kasih banyak atas segala dukungan yang diberikan oleh FISIP UMJ, baik secara materi maupun moril kepada tim, juga kepada staf Humas KemenPPPA dan pengelola Jurrnal UAI sehingga kami mampu menyelesaikan program ini dengan baik di tengah kondisi pandemi yang tengah melanda negeri dan berkesempatan untuk memublikasikannya, semoga program ini dapat memberi manfaat bagi masyarakat luas, khususnya para pelajar dan pelaku di bidang komunikasi.

\section{DAFTAR PUSTAKA}

Detik News (2020, Oktober) Kominfo Temukan 1.197 Hoax Terkait Isu Corona di Medsos, diakses di detikNewshttps://news.detik.com/berita/ d-5218475/kominfo-temukan-1197hoax-terkait-isu-corona-di-medsos

KEMEPPPA. (2019, April). Permasalahn Perempuan dan Anak Harus ditangani Bersama. diakses di: https://www.kemenpppa.go.id/index.php/pa ge/read/29/2111/permasalahan- perempuandan-anak-harus-ditangani-bersama

KEMENPPPA. (2016, Februari). Perkuat Koordinasi, Untuk Peningkatan Pemberdayaan Perempuan dan Perlindungan Anak. Website Resmi Kementerian Pemberdayaan Perempuan dan Perlindungan Anak. diakses di: https://www.kemenpppa.go.id/index.php/pa 
ge/read/30/413/perkuat-koordinasi-untukpeningkatan-pemberdayaan-perempuandan-perlindungan-anak

KEMENPPPA. (2020, Oktober). Protokol Kesehatan Keluarga (Ketika Beraktivitas di Luar Rumah. Di akses di https://www.instagram.com/p/CGOp309jv3 $\mathrm{h} /$ ?igshid=1 vsya0gp94ibx.

Larson, Charles U. (1992). Persuasion, Reception and Responsiblity. California: Wardsworth Publishing Company

Rosady Ruslan, SH., MM. (2008). Kiat dan Strategi Kampanye Public Relations. Jakarta: PT. Raja Grafindo Persada

Suhaya. Dede, (2020, Oktober). Waspada! Kampanye Hoax: Vaksin Covid-19 Bisa Mengubah Manusia Menjadi Monyet. Diakses di: https://zonapriangan.pikiranrakyat.com/internasional/pr46840040/waspada-kampanye-hoaxvaksin-covid-19-bisa-mengubahmanusia-menjadi-monyet
Venus, Antar. (2004). Manajemen Kampanye: Panduan Teoritis dan Praktis dalam Mengekfektifkan kampanye Komunikasi. Bandung: Simbiosa Rekatama Media

Yousuf, hamza, et all (2020). Association of a Public Health Campaign About Coronavirus Disease 2019 Promoted by News Media and a Social Influencer With Self-reported Personal Hygiene and Physical Distancing in the Netherlands. Diakses di JAMA Netw Open.2020;3(7):e2014323.doi:10.1001/jama networkopen.2020.14323 